\title{
ОБМЕЖЕННЯ ПРАВА НА СВОБОДУ ВИРАЖЕННЯ ПОГЛЯДІВ У РІШЕННЯХ СВРОПЕЙСЫКОГО СУДУ 3 ПРАВ ЛЮДИНИ
}

\begin{abstract}
КРАВЧЕНКО Віктор Віталійович - кандидат юридичних наук, доцент, доцент кафедри конституційного, адміністративного та фінансового права, Академії праці, соціальних відносин і туризму

ЖУРАВЕЛЬ Ярослав Володимирович - доктор юридичних наук, доцент, доцент кафедри конституційного, адміністративного та фінансового права, Академії праці, соціальних відносин і туризму

ХОВПУН Олексій Сергійович - доктор юридичних наук, доцент, доцент кафедри кримінального права, процесу та криміналістики
\end{abstract}

DOI 10.32782/LAW.UA.2021.3.2

У статті досліджуються обмеження права на свободу вираження поглядів Европейсъкого суду з прав люди викладених у його рішеннях.

Визначається, що право на вираження своӥх поглядів не є абсолютним. Як і більшість прав та основоположних свобод, гарантованих Конвениією про захист прав людини та основоположних свобод, воно може бути обмежене національними органами відповідних держав, які ратифікували Конвенцію. Проте такі обмеження, згідно з Конвениією, не можуть бути безмежними. Не дозволяється спотворювати право чи, тим більше, вихолощувати його зміст. Індивіди, право на свободу вираження яких обмежено, можуть звернутися до Европейсъкого суду з прав людини з вимогою перегляду такого обмеження на відповідність Конвениї.

Доводиться, щзо правотлумачна та правозастосовча діяльність Суду щодо захисту свободи вираження поглядів та й зрештою $i$ щоло інших прав суб'єктів має вагомий вплив на правову систему Украӥни.

Робляться висновки щодо критерїв, що використовує Суд при визнанні правомірними обмежень права на свободу вираження поглядів, що накладаються органами державной влади. Такі обмеження мають бути: передбачені законом, відповідати приниипам передбачуваності та прозорості; переслідувати одну iз иілей, передбачених статтею 19 Міжнародного пакту про громадянсъкі та політичні права, а саме: захист прав чи репутаиії інших осіб, захист інтересів національної безпеки чи громадсъкого порядку, охорону здоров'я або моралі; необхідними, а також найменш обмежуючим для досягнення відповідної иілі (принизи пропориійності).

Ключові слова: Європейсъкий суд з прав людини, Конвениія про захист прав людини та основоположних свобод, свободи, конституційні права, обмеження вираження поглядів, обмеження прав.

\section{Актуальність}

31 жовтня 1995 р. був прийнятий закон України "Про приєднання України до Статуту Ради Европи”. У 1997 р. Україна ратифікувала один із основних документів Ради Європи - Конвенцію про захист прав людини та основоположних свобод (далі Конвенція), яка, згідно зі ст. 9 Конституції України, стала частиною національного законодавства України. Вищевказані події дали можливість громадянам та іншим суб’єктам України, за дотримання певної процедури, здійснювати захист своїх прав у Європейському суді з прав людини (далі Суд).

Відомо, що право на вираження своїх поглядів не $є$ абсолютним. Як і більшість прав та основоположних свобод, гарантованих Конвенцією про захист прав людини та основоположних свобод, воно може бути обмежене національними органами відповідних держав, які ратифікували Конвенцію. Проте такі обмеження, згідно з Конвенцією, не можуть бути безмежними. Не дозво- 


\section{Теорія, історія держави і права, конституційне право}

ляється спотворювати право чи, тим більше, вихолощувати його зміст. Індивіди, право на свободу вираження яких обмежено, можуть звернутися до Европейського суду 3 прав людини (далі - Свропейський суд, або Суд) з вимогою перегляду такого обмеження на відповідність Конвенції. Стаття 18 Европейської Конвенції вказує на те, що «обмеження, дозволені згідно 3 цією Конвенцією щодо зазначених прав і свобод, не застосовуються для інших цілей, ніж ті, для яких вони встановлені».

Правотлумачна та правозастосовча діяльність Суду щодо захисту свободи вираження поглядів та й зрештою і щодо інших прав суб'єктів має вагомий вплив на правову систему України. Зважаючи на те, що Україна зараз має збройний конфлікт з сусідньою державою набувають актуальності випадки розповсюдження недостовірної інформації, що має вираження у тому числі і в обмеженнях щодо вираження поглядів, чим і зумовлення актуальність цього дослідження.

Список досліджень та публікацій за останні роки вказуе на унікальність для науковців висвітлювати спірні питання, що стосуються обмеження права на свободу вираження поглядів крізь призму аналізу прийнятих рішень Европейського суду 3 прав людини. Зокрема, висвітлення таких питань можливо знайти в працях: Нагні-чук O.I., Грищука О.В., Сердюка О.В., Яковюка I. В., Барабаш О.О., Можаровська К.В., Нагнічук O.I., Слінько Т.М., Шевчук С.В., Ярмо А.В. та інші.

Метою дослідження виступає комплексний аналіз обмеження права на свободу вираження поглядів у рішеннях Европейського суду з прав людини.

\section{Результати}

Генеза права на свободу вираження поглядів сягає середини XX століття, адже 10 грудня 1948 року Генеральною Асамблеєю ООН було прийнято Загальну декларацію прав людини, яка хоч i мала рекомендаційний характер, однак заклала підвалини створення міжнародно-правового механізму захисту прав людини і осно- воположних свобод, у тому числі і свободи вираження поглядів (Загальна декларація прав людини, 1948).

Для початку варто зазначити, що Европейський суд з прав людини (далі ССП $\mathcal{A}$ ) у своїх рішеннях керуються Конвенцією про захист прав людини і основоположних свобод (далі - Конвенція). Що стосується обмеження права на свободу вираження думок, то ч. 2 ст. 10 Конвенції передбачено: «Кожен має право на свободу вираження поглядів. Це право включає свободу дотримуватися своїх поглядів, одержувати і передавати інформацію та ідеї без втручання органів державної влади і незалежно від кордонів. Ця стаття не перешкоджає державам вимагати ліцензування діяльності радіомовних, телевізійних або кінематографічних підприємств. прямо передбачає, що обмеження права на вільне вираження поглядів не $\epsilon$ порушенням Конвенції, якщо ці обмеження були встановлені задля досягнення однієї 3 цілей, зазначених у пункті 2 статті 10» (Конвенція, 1950).

Таким чином, Конвенцією гарантовано право особи вільно виражати свої погляди. Проте ч. 2 ст. 10 цієї ж Конвенції відразу встановлено обмеження, а саме: «Здійснення цих свобод, оскільки воно пов'язане з обов'язками і відповідальністю, може підлягати таким формальностям, умовам, обмеженням або санкціям, що встановлені законом і є необхідними в демократичному суспільстві в інтересах національної безпеки, територіальної цілісності або громадської безпеки, для запобігання заворушенням чи злочинам, для охорони здоров'я чи моралі, для захисту репутації чи прав інших осіб, для запобігання розголошенню конфіденційної інформації або для підтримання авторитету i безсторонності суду» (Конвенція, 1950).

Свобода дотримуватися поглядів як складова частина права, передбаченого статтею 10 Конвенції, надає право особі мати власну позицію щодо того чи іншого питання, гарантує захист особи від приписування їй певної позиції на основі іï попередніх висловлювань і негативних наслідків, які можуть виникнути з цього, а також забороняє примушувати особу розголошувати іншим 
свою позицію. Держави не повинні намагатися розрізняти осіб, які дотримуються тієї чи іншої думки. Більше того, просування односторонньої інформації державою може становити серйозну i неприйнятну перешкоду свободі дотримуватися поглядів (Protecting the right, 2017 ).

Нагнічук О.I. зазначає, що втручання держави у здійснення особою права на свободу вираження поглядів не має чітко окреслених меж. Для того, щоб визначити, чи було втручання держави у здійснення особою права на свободу вираження, Суд окремо розглядає справу та виносить рішення про те, чи відбулося таке втручання, при цьому аналізуючи певні обставини реалізації права органами державної влади. Особливо небезпечними втручаннями, на думку Суду, є справи, що стосуються передачі інформації. Розглядаючи справи щодо публікації статей, Суд постановив: «У ст. 10 не міститься положення, яке забороняє попередні обмеження на публікацію... але це питання потребує особливої уваги 3 боку Суду, оскільки у вказаних обмеженнях закладено серйозну небезпеку. Особливо це стосується преси, так як затримка публікації може зовсім позбавити актуальності тієї чи іншої теми та іï цінності» (Нагнічук O.I., 2014).

У науковій літературі досить часто здійснюються спроби щодо узагальнення практики Суду. Також виділяються критерії, відповідно до яких Суд приймає рішення щодо обмеження свободи вираження поглядів. Зазвичай, Суд використовує (так званий триступеневий тест) при визнанні правомірними обмежень права на свободу вираження, що накладаються органами державної влади:

- чи було обмеження «встановлено закоHOM»;

- чи було воно «необхідним у демократичному суспільстві»;

- чи переслідувало обмеження «легітимну мету» (Грищук О. В, 2003).

Розглядаючи право на свободу вираження поглядів, необхідно зазначити, що воно тісно пов'язана з правом на захист честі та гідності, яке випливає 3 ч. 2 ст. 10 Конвенції. У цьому разі треба детально розібратись 3 поняттям фактів та оціночних суджень. У справі «入інгенс проти Австрії суд зазначив, що слід розрізняти факти та оціночні судження. Наявність фактів можна довести, а правдивість оціночних суджень - ні. У рішенні по цій справі Суд сформулював свою позицію стосовно ролі преси у суспільстві і можливості висвітлення політичних питань. Він зазначив, що «свобода преси дає громадськості одну 3 найкращих можливостей дізнатися про ідеї та позиції політичних лідерів і сформувати свій погляд на них. Відповідно, межі допустимої критики є ширшими, коли вона стосується власне політика, а не приватної особи ( Справа «Аінгенс проти Австрії», 1986).

Також у цьому контексті необхідно звернутись до відносно нового рішення ЕСПл «Сіреджук проти України» від 21.01.2016 р. У цій справі суд зазначив, що навіть оціночне судження може бути надмірним, якщо воно не містить фактів для їх підтримки, бо за відсутності таких доказів вони можуть розглядатися як такі, що принижують честь і гідність (Сіреджук проти України, 2016).

Таким чином, можливо аргументувати, що Суд при винесенні рішення керується різними критеріями, виходячи із обмежень законодавства країни, проти якої позиваються заявники.

Так, у справі «Норвуд проти Сполученого Королівства» заявник виставив у своєму вікні плакат, наданий Британською національною партією, членом якої він був, де було зображено вежі-близнюки у полум'ї. Картина супроводжувалася словами «Ілам з Британії - захищай британський народ!». Як наслідок, він був засуджений за розпалювання ворожнечі до релігійної групи. Суд визнав скаргу неприйнятною, посилаючись на статтю 17 Конвенції, яка забороняє будьяку діяльність, «спрямовану на скасування будь-яких прав та свобод, визнаних Конвенцією». Суд зазначив, що свобода вираження поглядів не може використовуватися для знищення прав та свобод, викладених у Конвенції. Така атака на релігійну групу, ототожнення релігійної групи загалом із тяжким актом тероризму є несумісними 3 проголошеними та гарантованими цінностями Конвенцією, зокрема такими як, то- 


\section{Теорія, історія держави і права, конституційне право}

лерантність, мир у суспільстві та недискримінація. Таким чином, будь-який вираз, що містить елементи релігійної дискримінації, виходить за межі дії статті 10 Конвенції (Norwood v. the United Kingdom, 2004).

Це не єдиний випадок, коли Суд у своїх рішеннях посилається на інші статті Конвенції, якими охороняються інші права. Тому можливо зробити висновок, що свобода вираження думок має межі відносно охорони інших прав та свобод, що мають пріоритет над свободою вираження думок та поглядів.

У своїй практиці прийняття рішень Комісія та Суд чітко вказують на те, що фактор «обов'язку і відповідальності» тісно пов'язаний з критерієм «необхідні в демократичному суспільстві». Наприклад, у справі «Хендісайд проти Великої Британії» Комісія встановила принцип, згідно 3 яким вона повинна вивчати «конкретне становище особи, яка здійснюе своє право на свободу вираження думки, а також обов'язки і відповідальність, пов'язані з цим становищем». Суд у справі «Хендісайд» відзначив важливість таких критеріїв, як вік аудиторії, до якої звернено публікацію, і можливий вплив на моральність молодих читачів. Враховуючи обставини цієї справи, Суд зазначив, що обмеження, накладені державою на видавця, були обгрунтованими (Handyside v The United Kingdom, 1976).

В іншій справі «Вейделанд та інші проти Швеції» 60 заявників були засуджені за розподіл листівок у середині школи, які, на думку національних судів, були образливими для гомосексуалістів. Заявники поширювали листівки від організації під назвою «Національна молодь», залишаючи їх у шафах учнів або на них. У листівках були, зокрема, твердження, що гомосексуалізм має «морально-руйнівний вплив на сутність суспільства» і є відповідальним за розвиток ВI $\curlywedge$ та СНІДу. ЕСП $\curlywedge$ по цій справі встановив, що ці заяви мали серйозні та упереджені твердження, навіть якщо в них були відсутні прямі заклики до актів ненависті. Суд наголосив на тому, що дискримінація за ознакою сексуальної орієнтації $є$ такою ж серйозною, як і дискримінація за расою, походженням або кольором. Він дійшов висновку, що порушення Конвенції не було, а втручання держави в реалізацію заявниками права на свободу вираження поглядів було обгрунтованим (Case of Vejdeland and others v. Sweden., 2012).

Насправді аналізуючи рішення Суду по справах, пов'язаних з обмеженнями права на свободу вираження поглядів та думок, можливо зустріти досить значну кількість справ, які стосуються випадків, коли Суд визнає обгрунтованими обмеження, що встановлені державами по відношенню до заявників.

Суд наголосив у справі «Зана проти Туреччини» 1997 року, що загальні принципи ст. 10 в повному обсязі застосовується до ситуацій, коли національна безпека та громадська безпека опинились під загрозою. Суд вважав, що заяви мера регіону, який стикнувся з тероризмом, у великому виданні могли посилити насильство, і що національні суди надавали достатні та відповідні причини для його арешту (Зана проти Туреччини, 1996)

Так само у справі «Сюрек проти Туреччини» (Сюрек проти Туреччини, 2001), яка стосувалася кримінального засудження власника газети за поширення сепаратистської пропаганди. Суд нагадав, що «у пункті 2 статті 10 Конвенції введено обмеження політичних виступів або дебатів з питань, що становлять суспільний інтерес». Однак, коли такі зауваження підбурюють до насильства, держави-учасниці користуються «ширшим полем розсуду», розглядаючи необхідність втручання у свободу вираження поглядів («Сюрек проти Туреччини», 2001).

Як уже зазначалося, приймаючи рішення щодо того чи іншого обмеження, національні органи влади керуються широкою свободою розсуду, але за цією свободою повинен бути контроль з боку наднаціональних органів. Для перевірки не достатньо лише того факту, що органи національної влади керуються своїм розсудом розумно, обережно і добросовісно (Грищук О. В., 2003). Кожне обмеження, що вводиться, обов'язково «повинно бути переконливим чином обгрунтоване».

Зазначені вище приклади стосувалися законних обмежень, що були визнані судом обгрунтованими. Так, при кожному своєму рішенні Суд керується такими аргумен- 
тами: по-перше, свобода вираження поглядів становить одну із фундаментальних основ демократичного суспільства; преса відіграє істотну роль у демократичному суспільстві; по- друге, правдивість оцінкових суджень не піддається доведенню; вид та суворість призначеного покарання також є чинниками, які слід брати до уваги під час оцінювання пропорційності втручання у право на свободу вираження поглядів; по-третє, межі допустимої критики щодо політиків, публічних лідерів, а за певних обставин і щодо державних службовців, можуть бути ширшими, ніж щодо приватних осіб.

\section{Висновки та пропозиції}

Таким чином, враховуючи норми Конвенції та практику ЕСП $\curlywedge$, можна встановити критерії, що використовує Суд при визнанні правомірними обмежень права на свободу вираження поглядів, що накладаються органами державної влади. Обмеження має:

- бути передбачене законом, відповідати принципам передбачуваності та прозорості;

- переслідувати одну із цілей, передбачених статтею 19 Міжнародного пакту про громадянські та політичні права,а саме: захист прав чи репутації інших осіб, захист інтересів національної безпеки чи громадського порядку, охорону здоров'я або моралі;

- бути необхідним, а також найменш обмежуючим для досягнення відповідної цілі (принцип пропорційності).

Тому, вирішуючи питання про наявність у справі порушення статті 10 Конвенції, ЕСПЛ застосовує так званий трискладовий тест (the three-part test): законність обмежень, легітимна мета, заради якої застосовувалось обмеження, та необхідність у демократичному суспільстві.

\section{Мiтература}

Загальна декларація прав людини, прийнята Генеральною Асамблеєю ООН від 10.12.1948 p. № 995_015. URL: http://zakon4. rada.gov.ua/laws/show/995_015

Конвенція про захист прав людини та основоположних свобод від 04.11 .50 р.-
№ 995_004. URL: http://zakon4.rada.gov.ua/ laws/show/995 004

Protecting the right to freedom of expression under the European convention on human rights. URL: http://www.inai.tn/wp-content/uploads/2018/11/20170718_Handbook-Freedomof-Expression-ENG.pdf.pdf

Нагнічук О. I. Обмеження реалізації права на свободу вираження поглядів та умови їх застосування відповідно до ч. 2 ст. 10 Конвенції про захист прав людини та основоположних свобод. Наукові записки НаУКМА. 2014. Т. 155: Юридичні науки. C. 31-35. URL: https://core.ac.uk/download/ pdf/149240867.pdf

Грищук О. В. Право на свободу вираження поглядів: проблеми обмеження. Бюлетень Міністерства юстиції України. 2003. № 7. С. 16-17 .

Рішення Європейського суду 3 прав людини «入інгенс проти Австрії» (1986). Практика Європейського суду 3 прав людини: Рішення. Коментар. Київ. Укр. Центр правничих студій, 1999. № 1.

Norwood v. the United Kingdom. 2004 URL: https://futurefreespeech.com/norwoodv-uk/

Handyside v The United Kingdom (App no 5493/72) ECHR 7 December 1976. URL: http://www.echr.coe.int.

Case of Vejdeland and others v. Sweden. 2012. URL: https://www.icj.org/case-of-vejdeland-and-others-v-sweden/

Справа "Сіреджук проти України" (Заява № 16901/03) від 21 січня 2016 року. URL: $\quad$ https://ips.ligazakon.net/document/ $\underline{\mathrm{SOO} 00812}$

Справа «Зана проти Туреччини». Заява № 69/1996/688/880, Страсбург, 25 листопада 1997 року. URL: https://www.legislationline. org/documents/id/9047

Справа «Сюрек проти Туреччини». Заява № 34686/97. Страсбург, 14 червня 2001 року. URL: https://hudoc.echr.coe.int/EN G\#\{\%22itemid\%22:[\%22001-64073\%22]\}

\section{References}

Universal Declaration of Human Rights, adopted by the UN General Assembly on 10.12.1948 № 995_015. URL: http://zakon4. rada.gov.ua/laws/show/995_015 


\section{Теорія, історія держави і права, конституційне право}

Convention for the Protection of Human Rights and Fundamental Freedoms of 04.11.50 № 995_004. URL: http://zakon4.rada.gov.ua/ laws/show/995_004

Protecting the right to freedom of expression under the European convention on human rights. URL: http://www.inai.tn/wp-content/uploads/2018/11/20170718_Handbook-Freedomof-Expression-ENG.pdf.pdf

Nagnichuk O.I. Restrictions on the exercise of the right to freedom of expression and the conditions of their application in accordance with Part 2 of Art. 10 of the Convention for the Protection of Human Rights and Fundamental Freedoms. Scientific notes of NaUKMA. 2014. T. 155: Juridical sciences. Pp. 31-35. URL: https://core.ac.uk/download/pdf/149240867. pdf

Grishchuk O.V. The right to freedom of expression: problems of restriction. Bulletin of the Ministry of Justice of Ukraine. 2003. № 7. S. 16-17.

Judgment of the European Court of $\mathrm{Hu}$ man Rights "Lingens v. Austria" (1986). The case law of the European Court of Human Rights: Judgment. Comment. Kiev. Ukr. Center for Legal Studies, 1999. № 1.

Norwood v. the United Kingdom. 2004 URL: https://futurefreespeech.com/norwood$\mathrm{v}-\mathrm{uk} /$

Handyside in The United Kingdom (App no 5493/72) ECHR 7 December 1976. URL: http://www.echr.coe.int.

The case of Vejdeland and others v. Sweden. 2012. URL: https://www.icj.org/case-ofvejdeland-and-others-v-sweden/

The case of Siredzhuk v. Ukraine (Application no. 16901/03) of 21 January 2016. URL: https://ips.ligazakon.net/document/SOO00812

The case of Zana v. Turkey. Application № 69/1996/688/880, Strasbourg, 25 November 1997. URL: https://www.legislationline.org/ documents/id/9047

The case of Surek v. Turkey. Application № 34686/97. Strasbourg, 14 June 2001. URL: https://hudoc.echr.coe.int/ENG\#\{\%22item id\%22:[\%22001-64073\%22]\}

\section{RESTRICTIONS ON THE RIGHT TO FREEDOM OF EXPRESSION OF OPINIONS IN JUDGMENTS OF THE EUROPEAN COURT OF HUMAN RIGHTS}

The article examines the restrictions on the right to freedom of expression of the European Court of Human Rights set out in its judgments.

It is determined that the right to express one's views is not absolute. Like most rights and fundamental freedoms guaranteed by the Convention for the Protection of Human Rights and Fundamental Freedoms, it may be restricted by the national authorities of the States concerned which have ratified the Convention. However, such restrictions under the Convention cannot be unlimited. It is not allowed to distort the law or, moreover, to deplete its content. Individuals whose right to freedom of expression is restricted may apply to the European Court of Human Rights to review such a restriction for compliance with the Convention.

It is argued that the legal and law enforcement activities of the Court to protect the freedom of expression and, ultimately, to other rights of the subjects have a significant impact on the legal system of Ukraine.

Conclusions are drawn on the criteria used by the Court in recognizing the restrictions on the right to freedom of expression imposed by public authorities as lawful. Such restrictions must be: provided by law, comply with the principles of predictability and transparency; pursue one of the objectives set out in article 19 of the International Covenant on Civil and Political Rights, namely, the protection of the rights or reputations of others, the protection of national security or public order, the protection of health or morals; necessary, as well as the least restrictive to achieve the relevant goal (principle of proportionality).

Key words: European Court of Human Rights, Convention for the Protection of $\mathrm{Hu}-$ man Rights and Fundamental Freedoms, freedoms, constitutional rights, restriction of expression, restriction of rights. 